\title{
Research Trends in Open Innovation and the Role of the University
}

\author{
Carlos de las Heras-Rosas *(D) and Juan Herrera *D \\ Department of Economics and Business Administration, Universidad de Málaga, 29071 Málaga, Spain \\ * Correspondence: chr@uma.es (C.d.1.H.-R.); juanherrera@uma.es (J.H.)
}

Citation: de las Heras-Rosas, C.;

Herrera, J. Research Trends in Open Innovation and the Role of the University. J. Open Innov. Technol. Mark. Complex. 2021, 7, 29. https:// doi.org/10.3390/joitmc7010029

Received: 27 December 2020 Accepted: 9 January 2021 Published: 13 January 2021

Publisher's Note: MDPI stays neutral with regard to jurisdictional clai$\mathrm{ms}$ in published maps and institutional affiliations.

Copyright: (C) 2021 by the authors. Licensee MDPI, Basel, Switzerland. This article is an open access article distributed under the terms and conditions of the Creative Commons Attribution (CC BY) license (https:// creativecommons.org/licenses/by/ $4.0 /)$.

\begin{abstract}
Innovation is a key aspect for the sustainability and competitiveness of organisations, and of the economy in general. In recent years, Open Innovation (OI) has burst onto the scene as a more open approach, in which the sources and exchange of knowledge are extended beyond organisational borders. One of the main actors and providers of knowledge is the University. The literature related to $\mathrm{OI}$ and the University is very prolific, but at the same time dispersed. This paper aims to expand on the trend in research on OI and University. To do this, bibliometric techniques have been used to analyse a sample of 349 articles from journals indexed in the Web of Science (WoS) between 2005 and 2020. The results suggest that there is a high level of interest in research on this subject and that it is in full swing. The focus of the research is on topics such as collaboration, business-industry, RED, networks, performance or knowledge-transfer. Emerging themes such as knowledge-spillover or absorptive-capacity appear, which are related to the research sensitivity on the true use of the knowledge generated. In recent years, there has been a trend towards research into entrepreneurship, key aspects of R\&D such as strategy and cooperation, or education management. With regard to research related to University-Enterprise cooperation, the focus has been on SMEs, Helix models, entrepreneurship, or commercialisation. Finally, there are areas of research that require greater development related to family businesses and SMEs. This work sheds light on the state of the literature related to OI and University and is very useful for the orientation of future work in the field of research.
\end{abstract}

Keywords: open innovation; R\&D; knowledge transfer; absorptive-capacity; university; business; university-business; SciMAT

\section{Introduction}

Innovation management in organisations has become a fundamental aspect for the sustainability and competitiveness of both companies and the economy in general [1,2]. Researchers have been interested in innovation for more than a century. This early research was based almost exclusively on technological inventions, which were typical of advances in industrial innovation, where science and technology played a leading role [3,4]. Today, we are faced with a wide range of forms of innovation. Some approaches are still oriented to the technological field, where topics such as radical or incremental innovation [5] or product and process innovation [6] are located. On the other hand, other forms of nontechnological innovation also appear, including organisational innovation $[7,8]$, managerial innovation [9], or institutional innovation [10]. Early conceptualisations of innovation defined it as a closed, internal process, hidden from external entities [11], where organisations felt driven by the possibility of gaining a competitive advantage through patents and control of intellectual property [12].

The current panorama has changed, with the latest research indicating the growing relevance of external sources of innovation [13]. Organisations cannot rely solely on their own Research and Development (R\&D) capacity, so they are increasingly involved in what Chesbrough [12] called Open Innovation (OI): “ . . the purposive inflows and outflows of knowledge to accelerate internal innovation and to expand the markets for external use of 
innovation, respectively ... ". Organisations adopt a more open approach to innovation, collaborating with external stakeholders by sharing knowledge, resources, and technology across organisational boundaries [14]. The boundaries of the organisation have become more permeable and innovation in the enterprise has moved from an internal location to a relational system that includes its external partners [15,16]. Open Innovation allows organisations to integrate and commercialise resources and capabilities complementary to those of their own structure, and thus to add value and maximise the benefits of innovative activity $[17,18]$. Different agents can participate in these external-internal and internalexternal knowledge flows: suppliers, collaborating companies, competitors, universities, technology centres and institutes, customers and government institutions.

Innovation within companies can be considered as the result of knowledge and collaboration networks distributed among different agents $[19,20]$. Before the irruption of the Open Innovation concept introduced by Chesbrough [12], the Triple Helix model [21] already advanced a means of collaboration between University, Industry and Government. In an environment where the importance of knowledge is increasing, the University has been positioning itself more and more in the institutional firmament. In this way, the University has changed its merely academic and research role to present itself as an entrepreneurial university [22] and with a certain business character [23-25]. The commercialisation of academic knowledge, through the granting of patents and other forms of invention, constitutes an immediate and measurable acceptance of the University's research work [26]. This evolution of the role played by the University has increased the interest of the scientific literature in this field and drawn attention in the political community $[27,28]$. Similarly, companies have been increasing their technological level, which brings them closer to a more academic and research model $[29,30]$. These circumstances have facilitated a climate of collaboration between university and business which has aroused the interest of researchers, who have analysed the moderating elements and characteristics of this relationship [29-32].

\subsection{University-Business Collaboration Models}

Cooperation between universities and companies is presented as a tool for innovation and is growing considerably, although it is not exempt from elements that condition its viability and success. Galán-Muros and Plewa [33] analyse the factors which drive or stop cooperation between university and business, highlighting the role of the driving agents and the type of relationship. Another of the characteristics which distinguish this mode of collaboration is defined by the nature of the links which connect both organisations. When interorganisational links related to research are promoted between companies, the type of relationship may present different models, the relationship may be formally established through research and development alliances [34], it may also be focused on innovation along the supply chain [35], or on the other hand, this relationship may be based on informal social networks led by members of different organisations [36]. On the other hand, when these interorganisational links occur between companies and educational or research entities, the collaborative processes for innovation present a model with particular characteristics, which has generated a remarkable monitoring of the scientific community from different disciplines [37-39].

One of the differentiating elements that distinguishes the relationship between univers ity-business and business-enterprise is the role of the university as a trusted intermediary in innovation relations through its transfer offices [40]. Perkman [13] analyses the so-called academic commitment, which is defined as collaboration related to knowledge in which academic researchers and non-academic organisations participate, and in which there is room for both formal activities (collaborative research, contract research and consultancy) and informal activities (personalised advice, networks of contacts with professionals) [41,42]. The author of Reference [13] summarises and generally describes up to seven different links between university and business: research associations, research services, academic entrepreneurship, human resource transfer, informal interaction, commercialisation of 
property rights and scientific publications. In any case, the scientific literature has listed multiple classifications to describe these innovation links, according to the organisational level at which the links are maintained [43], according to the types of motivation and attraction between university and enterprise [39], according to the location of the collaborative entities [44], or the cases of cross-border collaboration of multinational enterprises [45], among others.

\subsection{Motivating Agents and Objectives of the Collaboration}

Universities are organisations that carry out the functions of teaching, research and knowledge transfer and play a key role in contemporary societies through their educational and knowledge-generating role. Recently, and driven in many cases by government initiatives, many universities are playing and promoting research links with private entities [46-50]. These government initiatives are extremely important and act as a motivating agent in this university-business relationship. The funding provided by local governments not only acts as a financial support for research, but also provides control mechanisms that can improve the outcome of such collaboration [51-53]. Research on the influence of governments on OI strategies is extensive, with cases considered from Poland [54], Portugal [55], Dubai [56], Spain [57], the Netherlands [58] and others. It shows how different government programmes and plans present a key element in the coordination and achievement of OI between university and business.

Likewise, it is worth asking how these collaborative processes take place and what objectives they pursue. In the study of university-business links, researchers have often used the number of patents, licences, specialised courses, entrepreneurial practices and research co-authorships to analyse what is the fruit of this relationship [59-61]. However, important information regarding the motivations and other organisational aspects that define this practice is in danger of being overlooked [13]. Other qualitative studies provide more in-depth aspects of relationships $[62,63]$ which, while describing more detail about relationship motivations, are less adequate to correctly measure the impact and consequences of the relationship.

Growing competition between suppliers of products and services, rapid market developments and also growing pressure from different social groups, have led companies to seek new practices in order to remain competitive [64]. The university, for its part, is in a dynamic of knowledge dissemination beyond the borders of its organisation, where the creation of companies derived from the university is positioned as a successful model of knowledge transfer [24]. The following question could be asked: What motivates companies and universities to collaborate and what benefits do they obtain? Numerous researchers have published on this subject, mostly through case studies $[44,45,65-67]$, where no clear consensus seems to have been reached on motivations and performance in the OI among these entities.

Inauen and Schenker-Wicki [68] analysed how the chosen partner influences the results obtained in an Open Innovation strategy to the outside. It shows how universities have a positive effect on innovation outcomes compared to negative outcomes when the partner is other cross-sector companies. Mention [69] indicates how information from competitors can negatively influence the degree of novelty of innovation. Cruz-González et al. [70] describe the influence that formal liaison devices and the absorption capacity of organisations have on the outcome of Open Innovation techniques, in relation to knowledge acquisition and the impact on product novelty.

Patents are one of the main results of R\&D activities [71]. One of the most visible consequences of OI techniques is intellectual co-ownership or co-patents. When the innovation partners are other industries or companies, problems with the appropriation of the value of industrial property become more evident. On the other hand, if the partner is the university, the co-ownership is associated with greater value in the market and in many cases, with greater scientific dissemination [72], aspects that benefit both participants. 
Economic innovation and sustainability have been other objectives sought by companies in their Open Innovation strategies, although they may conflict in certain cases [64]. It is also necessary to analyse the behaviour of individuals towards Open Innovation and what are their challenges and motivations for this practice. Significant changes in the nature of research and in the behaviour of organisations in general are required to facilitate the external engagement that researchers need to make [73]. The main factors for a researcher to participate in an exchange of knowledge transfer are multiple, in addition to personal, professional and institutional recognition, the use of social networks and the impact on them stands out as one of the main drivers [74], so this type of platform between universities and companies should be encouraged.

\subsection{The Absorption Capacity and Size of the Company}

Another key aspect for an organisation to obtain a satisfactory performance in its strategy of acquisition of external knowledge is the capacity of absorption. The expected benefits of Open Innovation practices are not assured and will depend on how prepared the company is to adopt and adapt this new source of knowledge [75-78]. In this respect, we can mention the "not invented here" syndrome analysed by Katz and Allen in 1982 [79]. The capacity of organisations to absorb external knowledge has focused the scientific stream in a large number of cases, where research has been carried out on how companies can better develop their capacities to search for, acquire and implement technology and knowledge $[80,81]$. The absorption capacity of an organisation has been related to the source of origin and the type of formal or informal relationship between the partners [70], and it has also been found that companies that hire specialised public and private science-based organisations demonstrate greater absorption capacity [82]. Miller et al. [83] distinguish five factors that influence the understanding of knowledge transfer: the human being, organisational factors, the characteristics of the knowledge transferred, power relations between collaborators and the characteristics of contact networks. However, not enough theoretical perspectives have yet been included to relate absorption capacity to other more developed topics, such as management, marketing or organisational behaviour [14]. It is therefore not enough to look for good 'travelling companions' in Open Innovation. The organisation must be prepared to recognise the value of new information, assimilate it and apply it for commercial purposes [84].

Another of the factors that condition Open Innovation practices between the university and companies is the size of the business organisations, mainly due to the available resources, the objectives sought and the OI techniques employed. The majority of small and medium enterprises (SMEs) do not carry out formal R\&D activities [85] so they depend on OI more than large corporations for effective innovation [86,87]. Many SMEs are involved in OI initiatives [86,88], but they face significant challenges in managing OI practices [89-91], as they generally have limited resources for innovation and unstructured internal capabilities [85]. However, SMEs also have some characteristics which show them to be more desirable partners for the OI than large organisations, as they are more flexible in decision-making and assume greater risks, and in many cases, they are also distinguished by their highly specialised knowledge in a given field [92].

SMEs are somewhat more reluctant to collaborate with other companies in the same sector, but they do find partners in universities and transfer offices more suited to their needs. D'Angelo and Baroncelli [65] argue that SMEs' collaboration with universities has a positive impact on product innovation, but not so much on innovation performance. Universities or other knowledge organisations qualify SMEs as very important collaboration partners, while SMEs do not consider these institutions to be equally important, since the fruit of the relationship is associated with an improvement and nuance of the knowledge that the company already had, and not with an industrial novelty itself [93]. 


\subsection{Justification and Objectives of the Research}

Research on Open Innovation is booming, although the many approaches and the different typologies of the collaborating agents mean that there is no clear consensus on this subject. The field of study is very broad and fragmented. In the last 15 years, Open Innovation has become an area of growing interest for researchers. The number of manuscripts referring to this concept is increasing and it is possible to find special issues of journals entirely dedicated to Open Innovation, such as: Technovation 31, 1 [94], Research Policy 43, 5 [95], International Conferences: World Open Innovation Conference WOIC [96], Conference of Open Innovation Association Fruct 2020 [97], or Journals and books whose main theme is Open Innovation: Journal of Open Innovation Technology Market and Complexity [98], and Researching Open Innovation in SMEs [99].

Within the field of research on Open Innovation, we believe that the role of the university deserves special attention. This research focuses on the analysis of the literature dealing with Open Innovation and the university. The aim is to give visibility to broadening knowledge through analysis of the research and scientific results of publications on this subject. This research pursues two main objectives: on the one hand, it seeks to obtain a global perspective of the evolution of research with respect to university-business collaboration within the framework of the OI, for which a descriptive statistical analysis of the main activity indicators in the published literature is carried out. On the other hand, bibliometric techniques are used to visualise which topics have been most important in the related literature in this field, highlighting those that lead and have led the research activity in recent years. Therefore, the purpose of this research is to gather in a document, by means of bibliometric techniques, the most important issues and orientations in the analysis of Open Research and university in the last years, in order to help companies and universities to make decisions about their Open Innovation strategy.

The techniques used allow us to show a detailed study of the evolution of the research carried out through longitudinal and strategic maps of the topics addressed with the greatest interest.

The present manuscript consists of four parts: (a) introduction, where the most important factors within the Open Innovation strategies have been presented, (b) description of the methodology and materials used, (c) results, where the literary production on Open Innovation and university, evolution of keywords, longitudinal analysis, strategic maps by periods and evolution of cooperation between university and business are analysed, and (d) discussion, conclusions and limitations of the research.

\section{Methods}

The aim of this research is to analyse what the research trends have been with respect to Open Innovation and the role of the university. To this end, bibliometric techniques are used that will allow us to analyse the published material from an objective perspective by organising the information contained in each manuscript [100]. The metric analysis carried out on the bibliography will allow us to consider what the main research topics in this field are, as well as the relationship between them. In this way, useful information will be generated for researchers and other interest groups that evaluate scientific activity on this subject $[101,102]$.

\subsection{Materials}

To conduct the research review on OI and University, the Web of Science (WoS) [103] database was searched. The reason for choosing this database was that it provides bibliographical data and related information on high-level publications, from the perspective of scientific quality. The search was carried out in September 2020. The search parameters were "Open Innovation" and "Universit" included in the Science Citation Index Expanded (SCI-Expanded), Social Sciences Citation Index (SSCI) and Emerging Sources Citation Index (ESCI), without limiting the year of publication. For this research, our interest lies in finding articles that contain the references 
"Open Innovation" and "University", either in the title of the publication, in the keywords or in the abstract. Likewise, and due to the different disciplines that address this topic, we have not limited the search by areas of knowledge.

This search configuration reported a total of 381 WoS items. From here, the first step taken by the authors was to identify which articles did not correspond to the topic being searched. The titles and abstracts of the sample found were read, and after a joint evaluation, a total of 32 papers were discarded as not suitable for the analysis and subject matter of this research. With regard to the relevance of the sample, no articles were discriminated against in relation to the number of citations obtained, since in recent articles this distinction could leave out of the bibliometric analysis recent articles that had not yet reached their highest level of impact. The sample selected for bibliometric analysis is restricted to a total of 349 articles.

To carry out the longitudinal analysis of the literature that researches Open Innovation with the university, firstly, the periods to be analysed were established. The criterion used tries to keep a balance between the time that each period comprises and the number of publications, however, taking into account the short space of time, barely 15 years, and following the criterion of establishing the maximum possible periods to enrich the longitudinal analysis, priority was given to temporalisation over the number of published manuscripts, with the distribution in terms of documents being unbalanced, above all, by the high number of publications in the last period. Thus, three periods were established, the first of 8 years between the years (2005-2012) with 64 documents, the second of 4 years (2013-2016) with 114 documents and the last with another 4 years (2017-2020) with 171 documents (Table 1). In order to achieve the maximum balance of representation and to allow a rigorous analysis, the sample was subjected to the filters that the software provides for the establishment of its weighting.

Table 1. Periods and number of documents per period.

\begin{tabular}{ccc}
\hline Number & Period & No. of Documents \\
\hline 1 & $2005-2012$ & 64 \\
2 & $2013-2016$ & 114 \\
3 & $2017-2020$ & 171 \\
\hline
\end{tabular}

Source: Prepared by the authors on the basis of SciMAT data.

\subsection{Software}

The SciMAT software was used for the construction of the longitudinal and strategic maps and thematic networks. The choice of this software is due to the fact that, despite the fact that there are many tools that allow scientific mapping, see Bibexcel, CiteSpace II, Co PalRed, IN-SPIRE, Gephi, VantagePoint or VOSViewer, among others, SciMAT [104] synthesizes most of the advantages of the existing tools, in addition to allowing longitudinal analysis, the essential objective of this work. The configuration was as follows: the author's keywords and the keywords from the source were used as the unit of analysis. To build the networks, co-occurrences have been used. To normalise the network, the equivalence index was used as a measure of similarity. Finally, to create the scientific map of topics and their networks, the single-centre clustering algorithm was used.

In order to represent the evolution of literature, we used longitudinal maps (Figure 1, left). These allow us to observe which themes have been formed in the previously established periods and what their evolution has been over time. To observe the role played by a theme in the field of research, we used strategic maps. These are divided into four quadrants (Figure 1, centre): (A) the driving themes, which symbolise the themes that lead the speciality, are well developed and important for the construction of the scientific field, (B) the basic themes, which are important for the scientific field but are not sufficiently developed, (C) the emerging or decadent themes, which are very underdeveloped and marginal, and (D) the peripheral themes, which are characterised by being very specialised. Finally, from each cluster or main theme that appears in the above maps, a network or 
network is formed, which is called a thematic network (Figure 1, right). This is formed through the interconnection of keywords based on the documents associated with each theme.

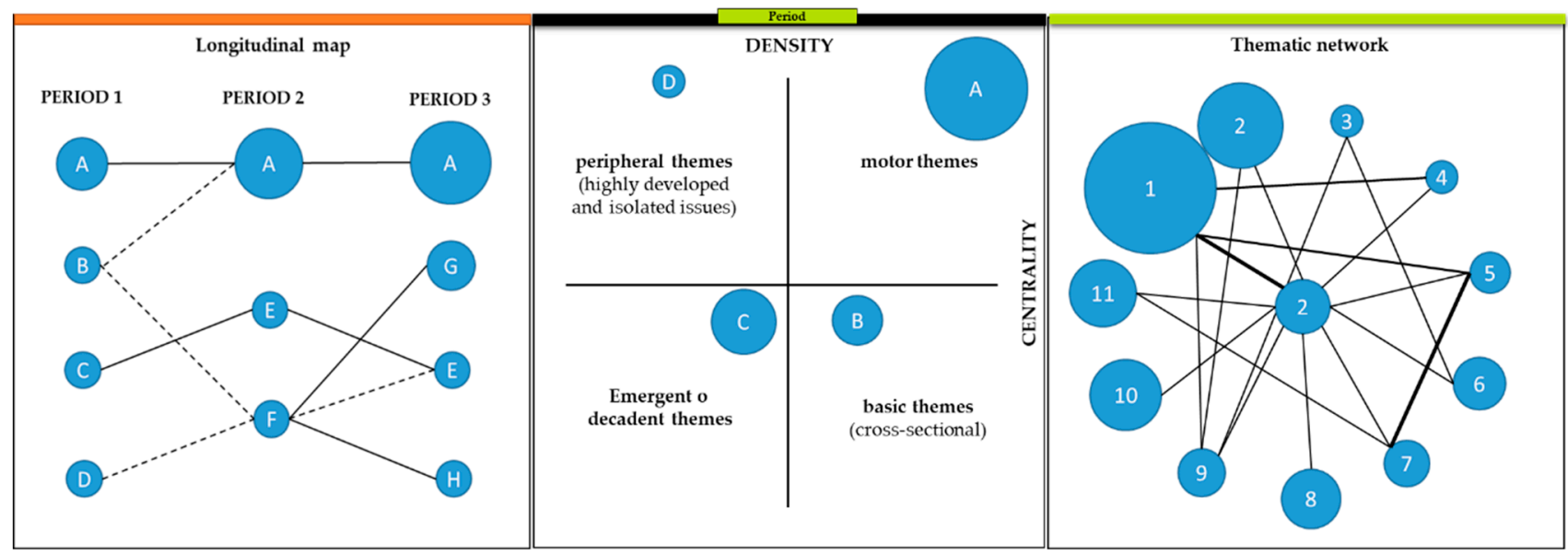

Figure 1. Example of a strategic map and thematic network. Source: Prepared by the authors of Reference [104].

\section{Results}

\subsection{Activity in the Literature on Open Innovation and the University}

The sample obtained in the search carried out in WoS on Open Innovation and university has reported a total of 349 articles. In this same database (WoS) and in the same period, the number of articles generally related to Open Innovation was 3300. The number of publications per year has not been homogeneous, describing a rising line from 2005 to 2020 (Figure 2). Considering that the concept of Open Innovation was coined by Chesbrough in 2003 [12], it is logical that production starts to emerge from the beginning of the 21st century.

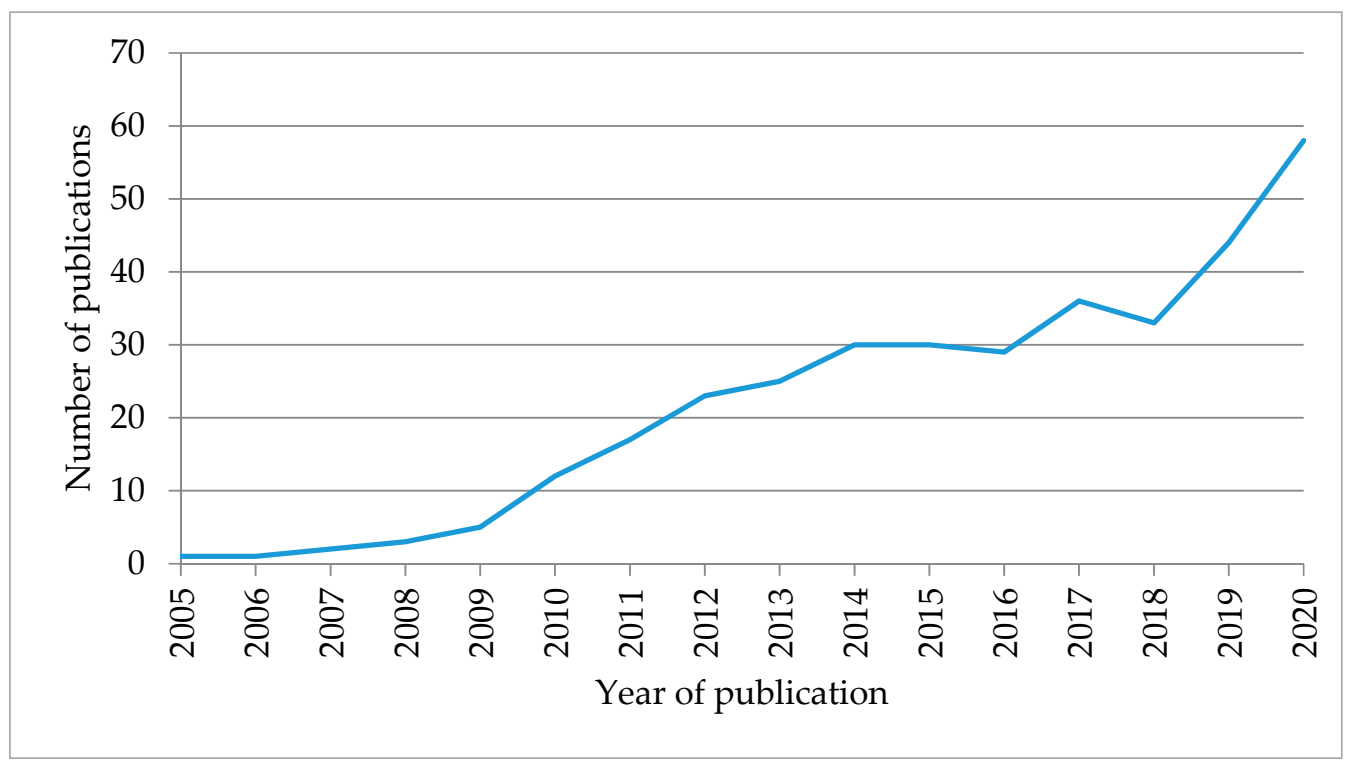

Figure 2. Publications over time on Open Innovation $(\mathrm{OI})$ and university $(n=349)$. Source: Prepared by the authors on the basis of WoS data.

In reference to the documents included in the Web of Science database, research on Open Innovation has been developed by a multitude of authors, including Lichtenthaler, $\mathrm{U}$. with 35 manuscripts, or Yun, JJ; Chesbrough, H; Bogers, M; Frattini, F; and Vanhaverbeke, W. over the 20 works published in WoS by each author. On the other hand, if what we are 
looking for are manuscripts on Open Innovation and university, which is the case of this research, in the sample obtained, no author stands out with a much higher production than the rest.

A total of 957 authors have participated in the 349 articles extracted from the database. No single author stands out particularly from the rest in terms of the number of articles published on this subject. Table 2 shows the authors with the greatest participation in this sample, the year of publication of their first and last article and the citations received from another research in the database used.

Table 2. Authors who have published three or more articles on Open Innovation and university.

\begin{tabular}{cccc}
\hline Author & Number of Articles & $\begin{array}{c}\text { Year of Publication } \\
\text { First and Last Article }\end{array}$ & Cited by \\
\hline Bengtsson, Lars & 4 & $2016-2020$ & 41 \\
Buganza, Tommaso & 4 & $2009-2019$ & 55 \\
Meissner, Dirk & 4 & $2014-2019$ & 48 \\
Di Minin, Alberto & 3 & $2016-2020$ & 3 \\
Albats, Ekaterina & 3 & $2018-2020$ & 21 \\
Bogers, Marcel & 3 & $2020-2020$ & 1 \\
Verganti, Roberto & 3 & $2009-2020$ & 38 \\
Secundo, Giustina & 3 & $2017-2020$ & 15 \\
Padilla-Melendez, Antonio & 3 & $2012-2020$ & 50 \\
Lockett, Nigel & 3 & $2010-2020$ & 44 \\
Ardito, Lorenzo & 3 & $2018-2019$ & 40 \\
van Geenhuizen, Marina & 3 & $2012-2018$ & 13 \\
Miller, Kristel & 3 & $2011-2016$ & 68 \\
Alexander, Allen T. & 3 & $2013-2015$ & 90 \\
Roper, Stephen & 3 & $2008-2013$ & 77 \\
\hline
\end{tabular}

Source: Prepared by the authors on the basis of WoS data.

The authors with the greatest participation have done so mostly in the last years of the sample, so that in some cases, the number of citations received will not yet have reached enough value. The most frequently cited documents in the sample do not appear in Table 2. Among the most frequently referenced are the theoretical articles in Tether and Tajar from 2008 [82] "Beyond industry-university links: Sourcing knowledge for innovation from consultants, private research organisations and the public science-base", with 280 citations, and Cooke's 2005 [22] "Regionally asymmetric knowledge capabilities and open innovation exploring 'Globalisation 2'-A new model of industry organisation", with 222 citations.

Table 3 shows the journals with the greatest presence in OI and university research. The sample of 349 articles has been published in 166 different journals, highlighting Technological Forecasting and Social Change with 15 publications distributed between 2011 and 2020. The impact factor percentile for 2019 of the 10 journals with the greatest number of publications in the sample is between Q1 and Q2. Some journals present impact factors with respect to different areas of knowledge; in this case, the quartile corresponding to the subject matter has been noted.

As with the large number of authors in the sample, the journals that have published on this subject are numerous and none stand out from the rest with a large number of publications, where the journal with the most articles published represents $4.3 \%$ of the total.

Regarding the origin of the published research, a count has been made of the affiliation of the first author of each manuscript in the sample. It has been preferred to refer to the first author of each publication to avoid errors in calculation caused by articles that present a large number of authors from the same country, compared to other research that is only associated with one or two authors. In this way, a fairly approximate figure is obtained for the countries where the greatest number of publications have been made on this subject. A total of 57 different countries appear as the place of affiliation of the first author of the articles in this sample. The countries with the highest number of publications are Italy with 
36 manuscripts, England with 35, the USA with 33, Spain with 32, Brazil and China with 16, Sweden with 13 and Germany and South Korea with 10 manuscripts each.

Table 3. Journals that have published on OI and university. Quartile 2019 and Total Items.

\begin{tabular}{|c|c|c|c|c|c|c|c|c|c|}
\hline N. & Journal & Q1 & Q2 & Q3 & Q4 & Total Items & $\%$ & First Doc. & Last Doc. \\
\hline 1 & Technological Forecasting and Social Change & $x$ & - & - & - & 15 & $4.3 \%$ & 2011 & 2020 \\
\hline 2 & Journal of the Knowledge Economy & $X(*)$ & - & - & - & 11 & $3.2 \%$ & 2011 & 2020 \\
\hline 3 & Research Policy & $X$ & - & - & - & 11 & $3.2 \%$ & 2005 & 2020 \\
\hline 4 & Int. Journal of Technology Management & $X$ & - & - & - & 10 & $2.9 \%$ & 2010 & 2019 \\
\hline 5 & Journal of Technology Transfer & $X$ & - & - & - & 10 & $2.9 \%$ & 2012 & 2020 \\
\hline 6 & R \& D Management & - & $x$ & - & - & 10 & $2.9 \%$ & 2009 & 2020 \\
\hline 7 & Sustainability & - & $x$ & - & - & 10 & $2.9 \%$ & 2017 & 2020 \\
\hline 8 & Business Horizons & - & $x$ & - & - & 9 & $2.6 \%$ & 2014 & 2019 \\
\hline 9 & European Journal of Innovation Management & - & $x$ & - & - & 9 & $2.6 \%$ & 2009 & 2020 \\
\hline 10 & Management Decision & - & $x$ & - & - & 8 & $2.3 \%$ & 2016 & 2020 \\
\hline
\end{tabular}

Source: Prepared by the authors on the basis of WoS data. X $\left(^{*}\right)$ Scopus. Q1, Q2, Q3 and Q4 correspond to the quartile of Journal Citation Report (2019).

In summary, we find that the study of Open Innovation and the university is a topic that is attracting the attention of researchers, which is reflected in the growing number of published manuscripts. Once the more generic bases on OI have been established and developed, specific aspects such as collaboration with educational entities and the set of factors that build this relationship are being investigated. Below, we analyse in more detail the issues that have been the focus of publications with respect to the OI and the university.

\subsection{Evolution of Keywords}

For the analysis of the evolution of keywords in the area, we use the methodology of Price and Gürsey [105] (Figure 3). In order to better understand this method, the circles represent the periods that have been established; in the case of this research, there are three. Inside each circle is the number of keywords for that period. The arrows that join the circles represent the keywords that are maintained from one period to another and, in brackets, the stability index or overlapping fraction is indicated. On the other hand, the arrows that enter and leave each circle symbolise the new keywords and those that are no longer used in the next period, respectively.

With regard to the results of the analysis, it should be noted that an increase of 124 new keywords is established between the first period (214) and the second (338), representing a growth of $58 \%$. The stability index between the first period and the second is (0.52), that is, slightly more than half of the keywords of the first period were maintained in the following period. Regarding the transition between the second (338) and third period (546), the increase was 208 new keywords, representing growth of $61.5 \%$. The stability index for these two periods was slightly lower than in the previous period (0.50). It is therefore evident that there is still a high growth in new lines of research and that there is no consolidation of the vocabulary by the scientific community when describing the documents published. It therefore provides an idea of the significant scope for development in this field of research.

\subsection{Longitudinal Analysis}

Having checked the evolution of keywords between periods, we focused on analysing how the literature related to OI and university has evolved. To do this, we will use a longitudinal map (Figure 4). The most central themes or clusters from each period appear on the map in the form of a sphere, with a label. In turn, through lines, it is represented with which other themes have been related in the following periods. The longitudinal map offers us various perspectives for analysis. Firstly, it is possible to find out which were the first topics with which the field of research was started (first period) and on which topics it is currently being researched (last period). Secondly, the longitudinal map offers us a perspective on the centrality of the themes over time. On the one hand, we can see those 
that maintain their leadership between periods and, on the other, those that are giving up that leadership in favour of other topics with which they are related, and which are accumulating greater prominence thanks to the increase in the centrality of their network.

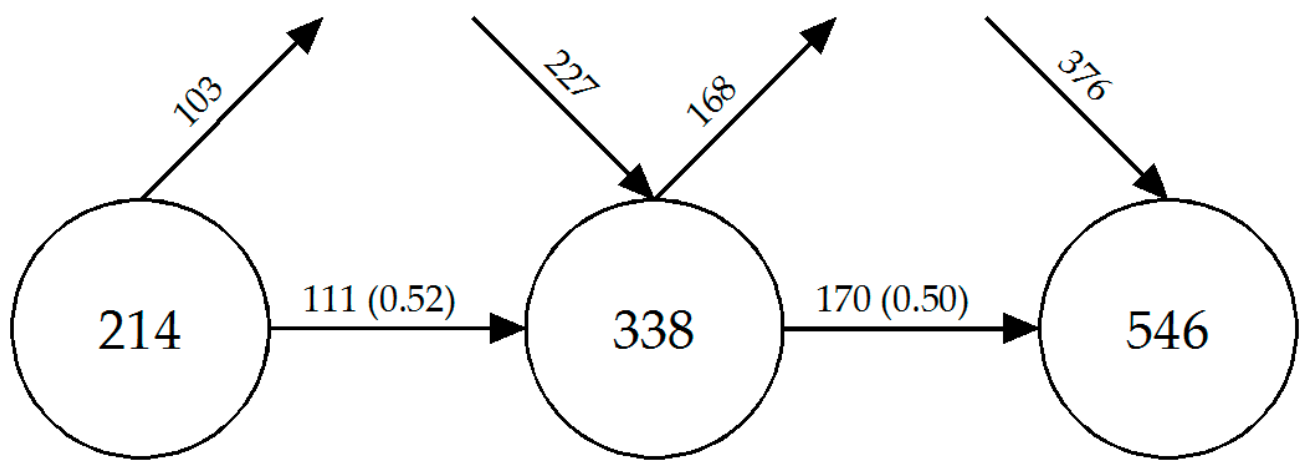

Figure 3. Keywords between periods. Source: Prepared by the authors on the basis of SciMAT data.

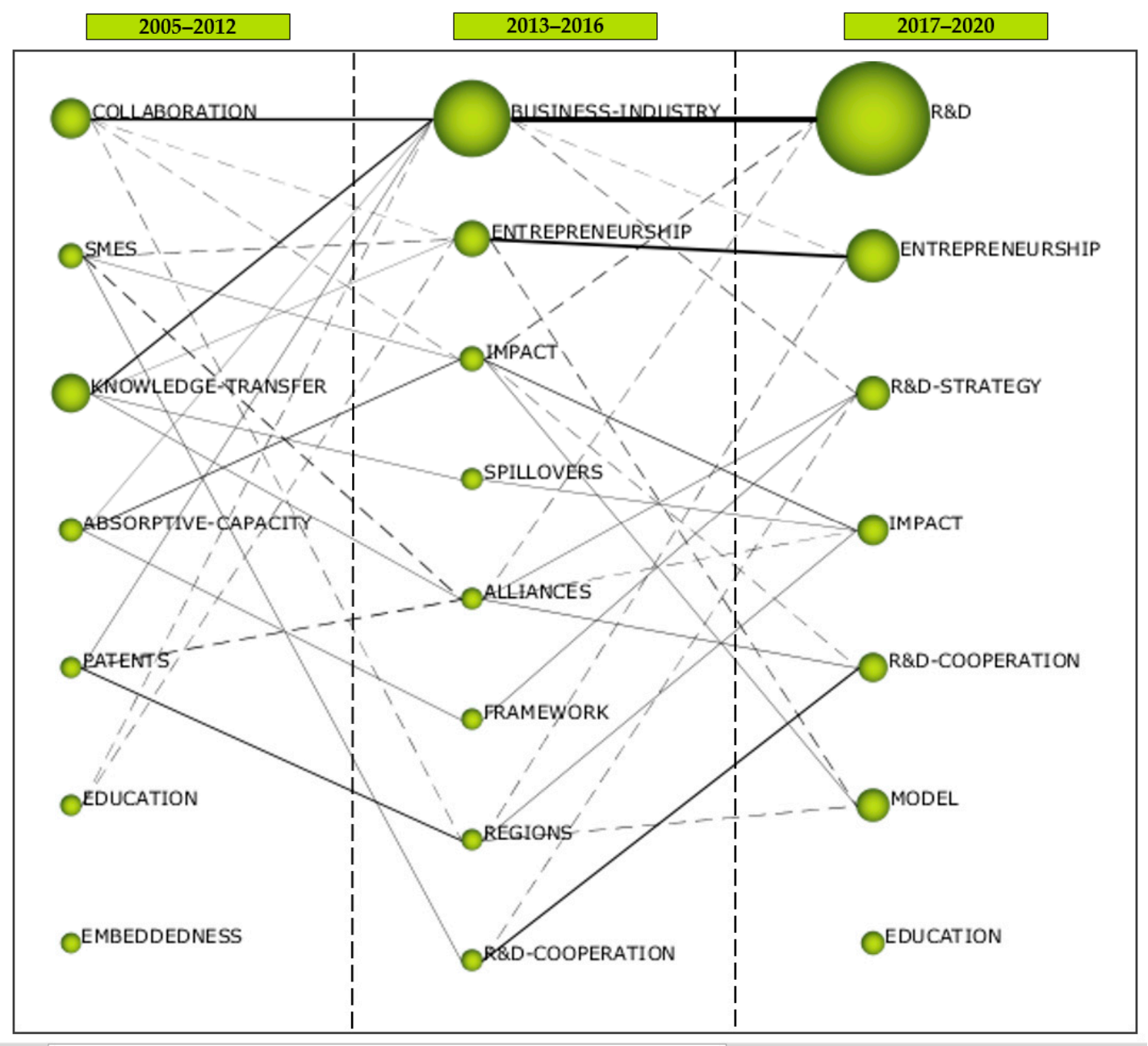

Figure 4. Evolution of the themes of primary documents. Source: Prepared by the authors on the basis of SciMAT data. The size of the sphere is proportional to the number of documents of the theme it represents, in relation to the other themes of the same period.

Entering into the analysis, we can observe how the topics with greater centrality in the first period and, as a consequence, those that propitiated the literature that related the terms 
OI and university, are (Table 4): collaboration, SMEs, knowledge-transfer, absorptive-capacity, patents, educations and embeddedness. From the quantitative point of view, collaboration and knowledge-transfer had a greater number of documents, 17 and 18 respectively, however, the first one had a higher range of centrality than the second (1.00 vs. 0.71$)$. In relation to the impact of the publications and their $\mathrm{H}$-index, the most relevant were collaboration (1367 citations, $\mathrm{H}$-index $=17$ ) and knowledge-transfer (1183 citations, $\mathrm{H}$-index $=18)$, together with absorptive-capacity (435 citations, $\mathrm{H}$-index $=6$ ) and patents (364 citations, $\mathrm{H}$-index $=3$ ). For the case of $S M E s$, although it has a relatively high $\mathrm{H}$-index (6), the number of citations is not high compared to the previous topics. To detect the topics that are most central to current research, we look at the last period. In this sense, $R \mathcal{E} D$, entrepreneurship, $R \mathcal{E} D$ strategy, impact, RED-cooperation, model and education are the ones that lead the research. Both from a quantitative and qualitative point of view, the themes or clusters of $R \mathcal{E} D$ (125 doc, 591 citations and H-index = 13) and entrepreneurship (45 doc, 206 citations and H-index $=8$ ) provide a higher level than the rest.

From the perspective of the evolution of the themes, the analysis of the sample allows us to see, in a first approximation, that there is no cluster that is maintained in the three periods with the same theme, although it is true that themes from the first or second period return to lead their clusters in the third period, such as entrepreneurship, impact, $R \mathcal{E D}$-cooperation and education.

As for the themes that have evolved in the following periods towards other clusters, we have:

- From a quantitative and qualitative point of view, collaboration/businesses-industry/ R\&D form the clusters with the largest number of documents and the highest number of citations. As for their internal structure, in addition to these three themes, they maintain over the different periods some of the most central themes of the research field, such as networks, performance or knowledge-transfer.

- In the case of the knowledge-transfer cluster, for the second period, it is dispersed in different clusters such as the already mentioned business-industry/R\&D, entrepreneurship/entrepreneurship, spill-over/impact, alliances/R\&D-strategy and alliances/R\&D-cooperation.

- The third theme that starts from the first period and that has some impact is absorptivecapacity which, like the previous one, is dispersed in business-industry/R\&D/impact, impact/impact and framework/R\&D-strategy.

- In the case of the SME cluster, its evolution has been towards the impact/impact and R\&D-cooperation/R\&D-cooperation clusters.

- As for the cluster patents, it has evolved towards the business-industry/R\&D and regions/impact clusters.

It can be concluded that the main issues initially supported by research on OI and university have been related to collaboration, knowledge-transfer, absorption capacity and, to a lesser extent, SMEs. On the other hand, the evolution of the topics over time has been dispersed, except in the case of collaboration which, although it has changed its subject, its core has persisted throughout the three periods. Finally, the topics which are currently leading research are included in clusters whose themes are related to $R \& D$, R\&D-strategy, R\&D-cooperation or entrepreneurship and, to a lesser extent, to impact, models and education. 
Table 4. Quantitative and qualitative factors of the themes and their evolution.

\begin{tabular}{|c|c|c|c|c|c|c|c|c|c|c|c|c|c|c|c|}
\hline \multirow[b]{2}{*}{ Name } & \multicolumn{5}{|c|}{ 2005-2012 } & \multicolumn{5}{|c|}{ 2013-2016 } & \multicolumn{5}{|c|}{$2017-2020$} \\
\hline & $\begin{array}{l}\text { Centrality } \\
\text { Range }\end{array}$ & $\begin{array}{c}\text { Density } \\
\text { Range }\end{array}$ & Docum & Citations & H-Index & $\begin{array}{l}\text { Centrality } \\
\text { Range }\end{array}$ & $\begin{array}{c}\text { Density } \\
\text { Range }\end{array}$ & Docun & Citations & $\begin{array}{c}\mathrm{H}- \\
\text { Index }\end{array}$ & $\begin{array}{c}\text { Central } \\
\text { Range }\end{array}$ & $\begin{array}{c}\text { yDensity } \\
\text { Range }\end{array}$ & Docum & Citations & $\begin{array}{c}\text { H- } \\
\text { Index }\end{array}$ \\
\hline Collaboration & 1.00 & 1.00 & 28 & 1367 & 17 & - & - & - & - & - & - & - & - & - & - \\
\hline SMEs & 0.57 & 0.86 & 8 & 151 & 6 & - & - & - & - & - & - & - & - & - & - \\
\hline $\begin{array}{l}\text { Knowledge- } \\
\text { transfer }\end{array}$ & 0.86 & 0.71 & 26 & 1183 & 18 & - & - & - & - & - & - & - & - & - & - \\
\hline $\begin{array}{l}\text { Absorptive- } \\
\text { capacity }\end{array}$ & 0.71 & 0.57 & 7 & 435 & 6 & - & - & - & - & - & - & - & - & - & - \\
\hline Patents & 0.29 & 0.43 & 3 & 364 & 3 & - & - & - & - & - & - & - & - & - & - \\
\hline Education & 0.43 & 0.29 & 3 & 118 & 3 & - & - & - & - & - & 0.14 & 0.57 & 6 & 15 & 2 \\
\hline Embeddedness & 0.14 & 0.14 & 2 & 127 & 2 & - & - & - & - & - & - & - & - & - & - \\
\hline $\begin{array}{l}\text { Business- } \\
\text { industry }\end{array}$ & - & - & - & - & - & 1.00 & 1.00 & 76 & 1755 & 23 & - & - & - & - & - \\
\hline Entrepreneurship & - & - & - & - & - & 0.88 & 0.62 & 26 & 643 & 14 & 0.86 & 0.86 & 45 & 206 & 8 \\
\hline Impact & - & - & - & - & - & 0.75 & 0.50 & 8 & 125 & 4 & 0.57 & 0.29 & 16 & 53 & 3 \\
\hline Spill-over & - & - & - & - & - & 0.38 & 0.88 & 4 & 122 & 4 & - & - & - & - & - \\
\hline Alliances & - & - & - & - & - & 0.62 & 0.12 & 4 & 86 & 4 & - & - & - & - & - \\
\hline $\begin{array}{c}\text { R\&D- } \\
\text { cooperation }\end{array}$ & - & - & - & - & - & 0.50 & 0.25 & 4 & 192 & 4 & 0.29 & 071 & 14 & 64 & 5 \\
\hline R\&D & - & - & - & - & - & - & - & - & - & - & 1.00 & 1.00 & 125 & 591 & 13 \\
\hline R\&D-strategy & - & - & - & - & - & - & - & - & - & - & 0.71 & 0.43 & 20 & 196 & 7 \\
\hline Model & - & - & - & - & - & - & - & - & - & - & 0.43 & 0.14 & 19 & 129 & 6 \\
\hline
\end{tabular}




\subsection{Analysis of Strategic Maps by Period}

After ascertaining the evolution of the themes over the periods, the research moves on to the analysis of the driving themes of each period. The aim is to analyse, firstly, the role of each of the clusters in the period and, secondly, the thematic network of the cluster that leads the field of research.

In the case of the 2005-2012 period, four driving themes were identified (Figure 5): collaboration, knowledge-transfer, absorptive-capacity and SMEs. Then, in the lower left quadrant appear education, patents and embeddedness, themes considered emerging or decadent, due to a low centrality and density. The main driving theme is collaboration, which has the highest degree of centrality and density. Its thematic network, from the point of view of the number of documents in which they appear, consists mainly of R\&D (22 doc), networks ( $20 \mathrm{doc})$, business-industry (19 doc) and performance (14 doc), however, in terms of the density of relations between network members, the following dyads stand out: (a) collaboration with R\&D, model, business-industry and networks, (b) challenges with commercialisation, (c) competence with model and commercialisation, (d) economy with networks, (e) model with R\&D and, finally, (f) R\&D with business-industry (Table 5).
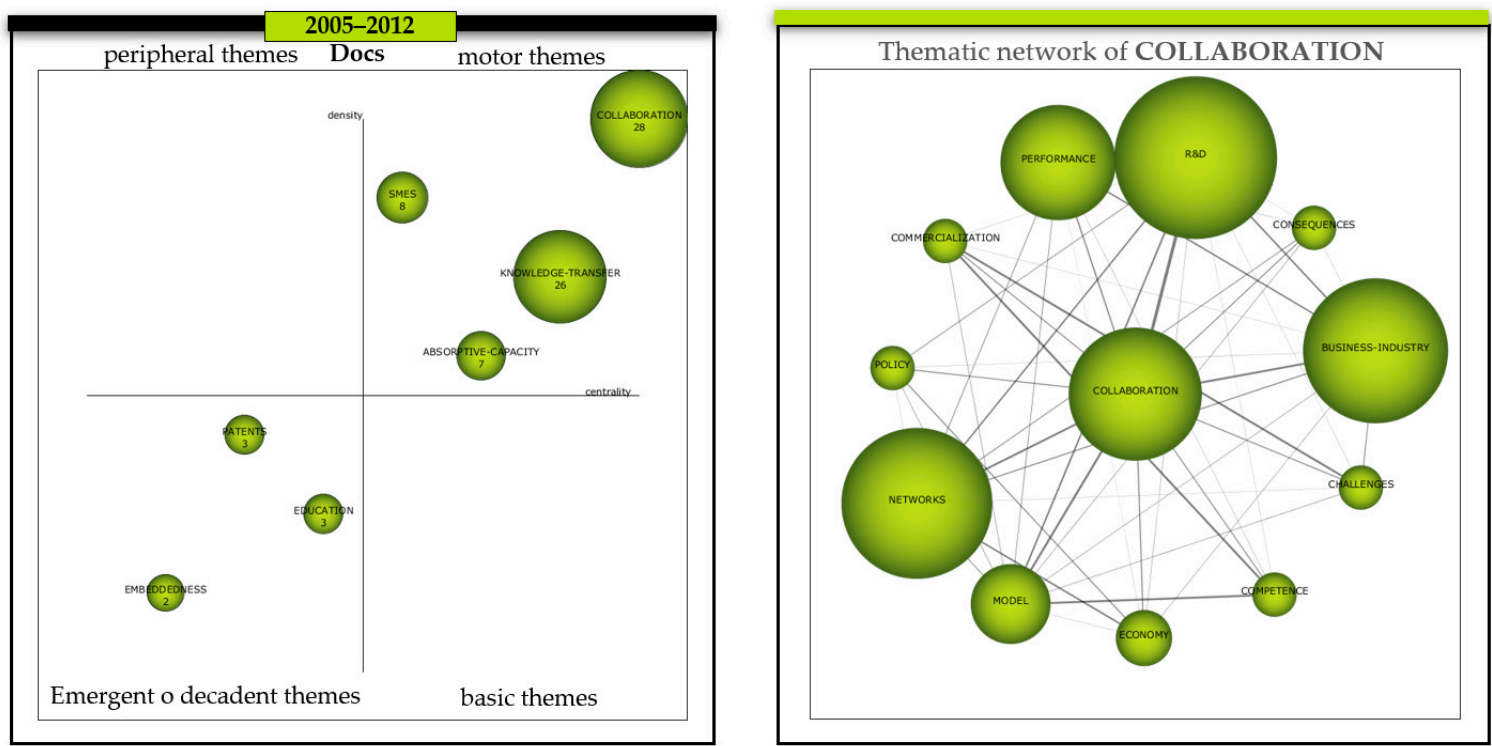

Figure 5. Evolution of the themes period 2005-2012 and thematic network of the cluster COLLABORATION. Source: Prepared by the authors on the basis of SciMAT data.

Table 5. Thematic network collaboration, 2005-2012. Ten relationships with more weight.

\begin{tabular}{ccc}
\hline Node A & Node B & Weight \\
\hline Collaboration & R\&D & 0.39 \\
Collaboration & Model & 0.26 \\
Challenges & Commercialisation & 0.25 \\
Collaboration & Business-industry & 0.25 \\
Competence & Model & 0.25 \\
Competence & Commercialisation & 0.25 \\
Collaboration & Networks & 0.24 \\
Economy & Networks & 0.20 \\
Model & R\&D & 0.20 \\
R\&D & Business-industry & 0.19 \\
\hline
\end{tabular}

Source: Prepared by the authors on the basis of SciMAT data.

In the case of the 2013-2016 period, there are two driving themes that lead this period of time (Figure 6): business-industry and entrepreneurship. The case of impact is at the frontier of the basic themes and the driving themes. The basic themes, together with 
impact, are alliances and R\&D-cooperation, which are on the borderline with the emerging or declining themes, which, in addition to the latter, contain the theme regions. The peripheral themes are spill-overs and frameworks. The theme with the greatest degree of centrality and density and, therefore, the most important driving force and leading research theme in this period is business-industry. The most important themes in its network in terms of the number of documents in which they appear are R\&D (38 doc.), knowledgetransfer ( 38 doc.), technology ( 36 doc.) and performance ( 29 doc.). With respect to the most common network topics: (a) performance with $\mathrm{R} \& \mathrm{D}$, business-industry and capabilities, (b) technology with business-industry and R\&D, (c) R\&D with business-industry, (d) absorptive-capacity with business-industry and management, (e) knowledge-transfer with business-industry and, finally, (f) knowledge with business-industry (Table 6).
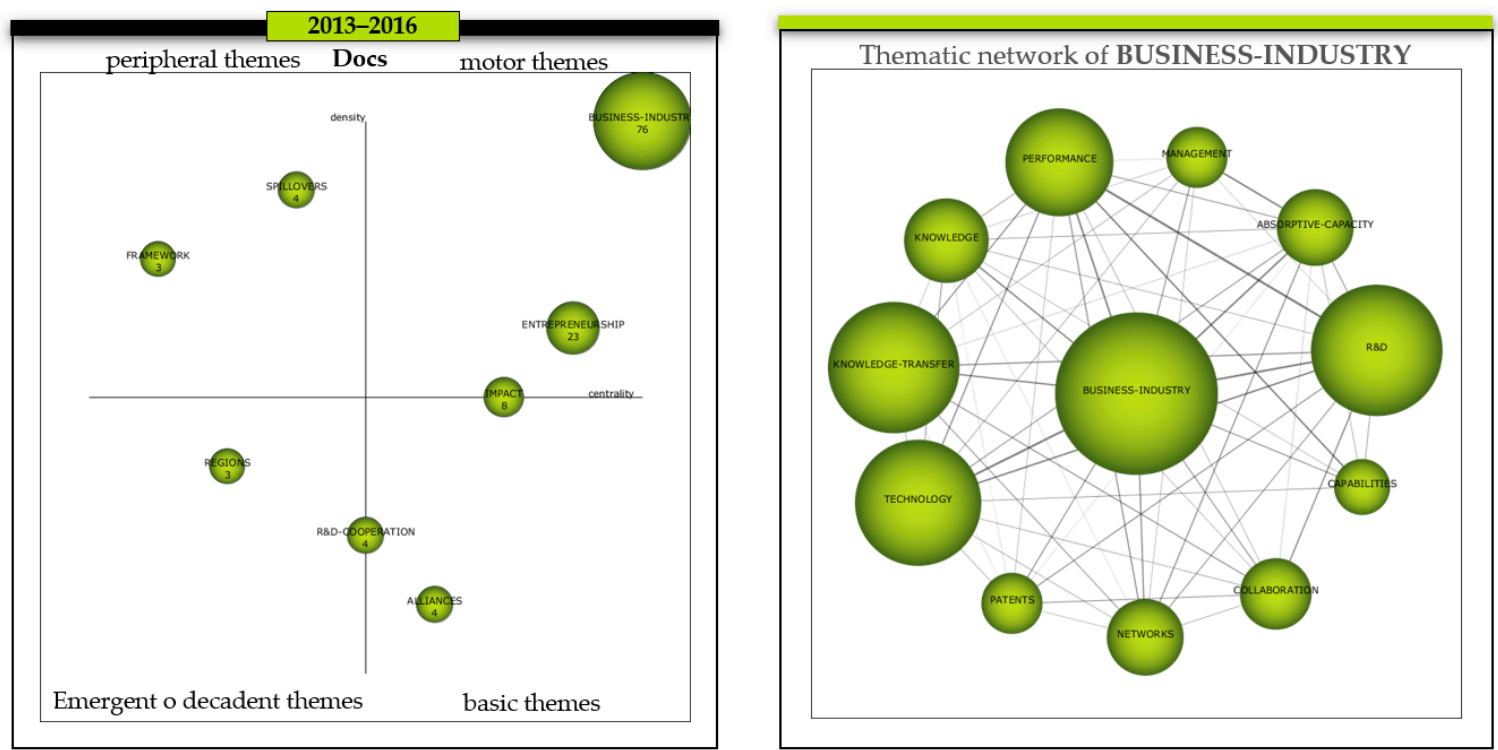

Figure 6. Evolution of the themes period 2013-2016 and thematic network of the cluster BUSINESS-INDUSTRY. Source: Prepared by the authors on the basis of SciMAT data.

Table 6. Thematic network business-industry, 2013-2016. Ten relationships with more weight.

\begin{tabular}{ccc}
\hline Node A & Node B & Weight \\
\hline Performance & R\&D & 0.26 \\
Technology & Business-industry & 0.24 \\
R\&D & Business-industry & 0.23 \\
Performance & Business-industry & 0.20 \\
Absorptive-capacity & Business-industry & 0.20 \\
Capabilities & Performance & 0.19 \\
Technology & R\&D & 0.19 \\
Management & Absorptive-capacity & 0.19 \\
Knowledge-transfer & Business-industry & 0.17 \\
Knowledge & Business-industry & 0.17 \\
\hline
\end{tabular}

Source: Prepared by the authors on the basis of SciMAT data.

With regard to the 2017-2020 period, once again, there are two driving themes which are leading this period (Figure 7); in this case, $R \& D$ and entrepreneurship. On the other hand, the basic themes are the R\&D-strategy and impact clusters. In the quadrant of peripheral themes, R\&D-cooperation and education appear and as an emerging or decadent model theme. For this last period, R\&D gives the name to the cluster that leads the sample of the literature of this research. This cluster, as mentioned above, is made up of a series of very cohesive themes that have remained over time. In this case, the topics in general have increased the number of documents in which they appear, among them are business- 
industry (75 doc.), R\&D (65 doc.), performance (56 doc.), knowledge-transfer (55 doc.), technology (47 doc.), collaboration (44 doc.), networks (39 doc.) and knowledge (38). In the case of the most network-density days there are: (a) R\&D with the themes of businessindustry, technology, performance and absorptive-capacity, (b) performance with businessindustry, knowledge, networks and technology, (c) technology with business-industry and, finally, (d) absorptive-capacity with business-industry (Table 7).
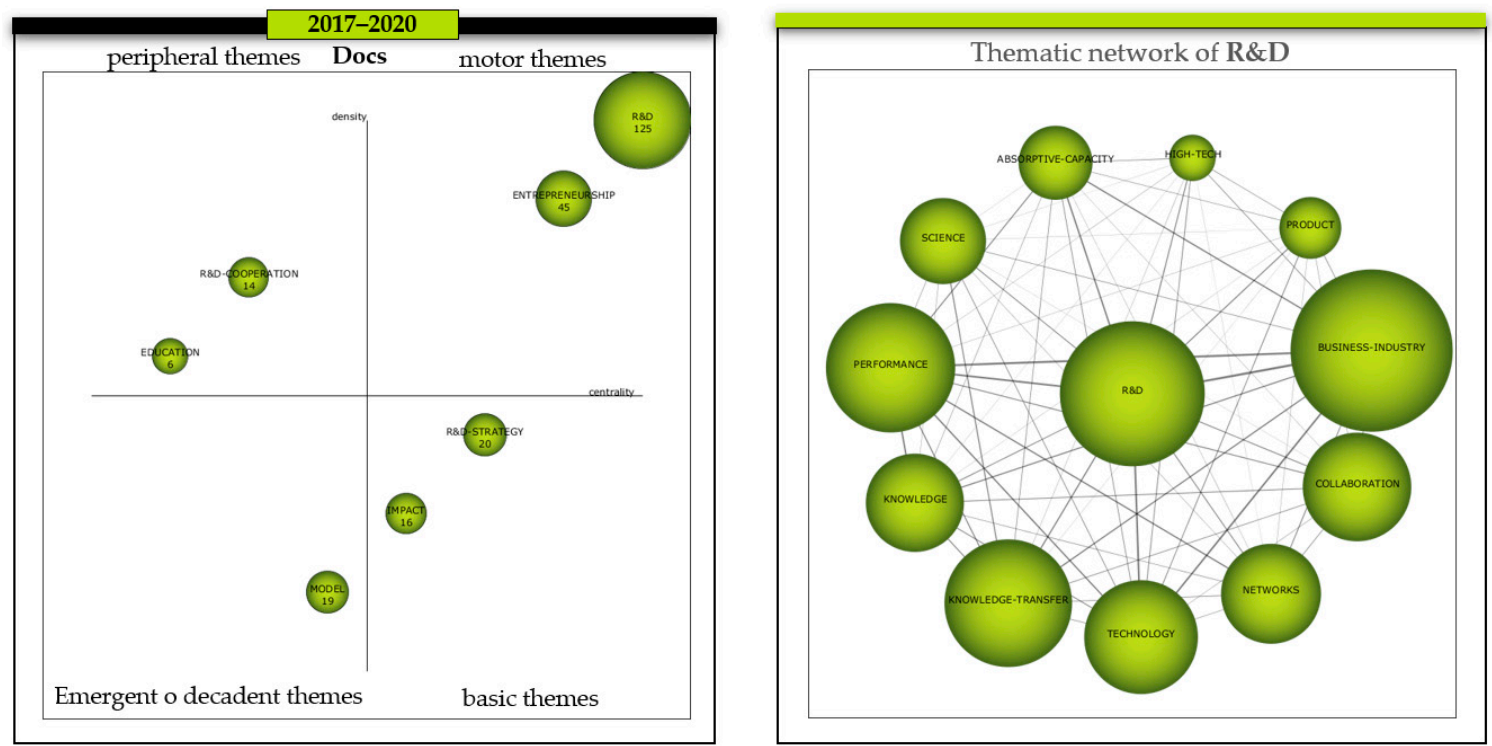

Figure 7. Evolution of the themes period 2017-2020 and thematic network of the cluster R\&D. Source: Prepared by the authors on the basis of SciMAT data.

Table 7. Thematic network R\&D, 2017-2020. Ten relationships with more weight.

\begin{tabular}{ccc}
\hline Node A & Node B & Weight \\
\hline R\&D & Business-industry & 0.27 \\
Performance & Business-industry & 0.24 \\
Technology & R\&D & 0.22 \\
Performance & R\&D & 0.22 \\
Technology & Business-industry & 0.21 \\
Knowledge & Performance & 0.19 \\
Absorptive-capacity & R\&D & 0.19 \\
Networks & Performance & 0.17 \\
Technology & Performance & 0.17 \\
Absorptive-capacity & Business-industry & 0.16 \\
\hline
\end{tabular}

Source: Prepared by the authors on the basis of SciMAT data.

\subsection{Analysis of the Evolution of the Theme University-Business-Cooperation}

This analysis aims to approach research from a different perspective. The aim is to gain a better understanding of which topics in the literature sample used in this research have used the theme university-business-cooperation (UBC). We start from the idea that, in addition to other topics, this is considered a central theme linking OI and university. The number of documents in which UBC appears in the period 2005-2012 was 13 documents, $20.3 \%$ of the total for the period. It belonged to the SMEs cluster. Among the main topics with which it was related, apart from SMEs, were R\&D-cooperation, science and information. In the period 2013-2016, UBC appeared in fewer documents proportionally (21), 18.4\% of the total for the period. Its network was also much less extensive. It was mainly related to entrepreneurship (name of the cluster), in addition to helix model and governance. As for the 2017-2020 period, UBC once again belonged to the entrepreneurship cluster. In terms of the number of documents in which UBC appeared, there was a substantial 
change. There was a total of 50 and it represented $29.2 \%$ of the total for the period. Its network was made up mainly of the helix model, entrepreneurship, commercialisation and knowledge-spill-over (Table 8).

Table 8. Thematic network university-business-cooperation.

\begin{tabular}{cccccc}
\hline \multicolumn{2}{c}{ 2005-2012 } & \multicolumn{2}{c}{ 2013-2016 } & \multicolumn{2}{c}{ 2017-2020 } \\
\hline Relations & Weight & Relations & Weight & Relations & Weight \\
\hline SMEs & 0.15 & Entrepreneurship & 0.12 & Helix model & 0.15 \\
R\&D-cooperation & 0.14 & Helix model & 0.05 & Entrepreneurship & 0.10 \\
Science & 0.12 & Governance & 0.02 & Commercialisation & 0.07 \\
Information & 0.10 & & & Knowledge-spill-over & 0.04 \\
Europe & 0.08 & & Start-ups & 0.03 \\
Service & 0.04 & & Country & 0.02 \\
Human-Capital & 0.04 & & & & 0.01 \\
Innovation- & 0.04 & & & \\
systems & 0.03 & & & \\
Public & 0.02 & & & & \\
Country & 0.02 & & & & \\
Organisation & & & &
\end{tabular}

\section{Discussion}

In the justification of this paper, it is true that there has been interest in innovation-related research for more than a century, but the current panorama is providing a different focus, giving special relevance to external sources of innovation, what Chesbrough [12] called Open Innovation. It is from here, from this new approach, that our research has considered to focus the analysis. The aim has been to broaden our knowledge of the literature on Open Innovation and the role played by the University. In this sense, we started from the idea that the objectives of this work were not to carry out a review of the literature in a deep and systematic way. We chose to design an analysis using bibliometric and mapping techniques, which allowed us to make visible, in a longitudinal and relational way, the evolution over time of the literature around the OI and the university. This work has generated a new focus and has shed light on the issues that have occupied more central positions, and which have led the interest of research from different perspectives. This methodology has also provided information on the quality of the publications analysed. It has also made it possible to ascertain the degree of maturity or saturation of the subject matter, where the research is heading, and which areas have not yet been sufficiently explored.

Deepening the analysis, in general and as expected, the results suggest that the bulk of the research linking OI and the university has to do with concepts that explain the development of Open Innovation and its relationship with the activity and role played by the university, such as collaboration, business-industry, R\&D, networks, performance or knowledge-transfer. On the other hand, due to the increased sensitivity of researchers towards the problems raised by the use of the knowledge generated, issues such as research into spill-overs or knowledge-spill-over, especially from the second period (2013), or absorptive-capacity, which emerge in the literature of the sample, are postulated as part of the theoretical corpus and are related at all times to performance, management, knowledge-transfer and networks, among others. With regard to knowledge-spill-over, the literature points out that, regardless of whether they are intentional or unintentional knowledge spill-overs, knowledge dissemination processes such as the presentation of business ideas or the challenge of Open Innovation, are important vehicles for effective and sometimes selective knowledge-transfer in an entrepreneurial ecosystem [106,107] Therefore, OI is a key channel for the exploitation of knowledge caused by knowledge spillage and its side effects. In relation to absorptive-capacity, the literature has shown that the expected benefits of OI are not assured and depend on the capacity of organisations to adopt and adapt new knowledge [75-78]. Therefore, companies are focusing on how to 
improve search capabilities and acquire and implement technology and knowledge [80,81]. At the same time, some studies point to a relationship between source and absorptive capacity [70], or firm size, due to structural constraints [85]. Research generally suggests that organisations need to be prepared to assimilate new information and reap the benefits of its application. As regards the attempt to provide another perspective in the analysis of the OI and university relationship, focusing on the university-business-cooperation issue and its relationship with the different topics, it has been possible to confirm that, except in the first period, which was related to SMEs and a more generic issue such as R\&D-cooperation, in the other periods, it should be noted that the research which was based on the university-business-cooperation nexus was mainly linked to topics such as entrepreneurship, the analysis of the different Helix models or commercialisation, linked to the modes of knowledge-transfer and as a motivating effect for the university.

Finally, it is important to make visible some shortcomings observed in the literature. For this reason, it should be pointed out that, despite the fact that OI is positioned as an important tool for the survival of family businesses [108], according to the sample analysed, research on OI and university related to family businesses has not been of any relevance, that is to say, it has been practically testimonial. It should be noted that this has not been the only exception, and research on SMEs has similar problems. In this sense, despite the fact that SMEs depend more on OI than large companies [108], the results of this work reinforce in a precise and convincing way what the literature has been demanding for some years, in the sense that research on OI in SMEs has received less attention than expected from researchers and practitioners [88,109-112]. Research has hardly concentrated on the first period (2005-2012), where it even formed its own cluster and was closely related to the theme university-business-cooperation and other themes such as innovation-system, R\&D-cooperation and human-capital. However, from the second period (2013), OI and university research related to SMEs has been practically non-existent.

\section{Limitations}

In this paper, the authors acknowledge that there are certain limitations to the research. On the one hand, there is the limitation of using documents exclusively from the Web of Science (WoS) database, as well as the limitation of using filters to achieve greater precision in the search for published research. On the other hand, that which may occur by relying exclusively on the concept of Open Innovation and not on its possible conceptual derivations.

\section{Conclusions}

The purpose of this paper has been to shed light on the literature investigating Open Innovation and the role of the university. Bibliometric techniques were used to analyse the literature on a sample of a total of 349 articles indexed in the Web of Science database. In terms of the evolution of the number of published research papers, it should be noted that since Chesbrough [12] introduced the concept of Open Innovation, a prolific period of research production around this concept has begun, from 2005 to date. It should also be noted that it was not until 2009 that it began to grow steadily, and that 2018 marks a turning point in which a new period of high growth in the number of research publications began. The sustained growth of production in research, together with the high rate of incorporation of keywords and its low rate of stability between periods, suggests that the field of research is of high interest to researchers and is in full development. In the longitudinal analysis, a set of cohesive themes was evident, which remain in the driving clusters of each period. These form the main core of research on OI and university over time. These include collaboration, business-industry, R\&D, networks, performance or knowledge-transfer. On the other hand, topics of interest to the research field emerged, such as knowledge-spill-over or absorptive-capacity related to research sensitivity on the true use of the knowledge generated. As for the possible trends constituted by themes that have been consolidated in the last period (2017-2020), it should be noted that important aspects of R\&D have become visible, such as strategy and cooperation, entrepreneurship, 
as well as research that has dealt with the management of education. Regarding research analysing cooperation between universities and companies, it should be noted that in the first period (2005-2012), it was mainly related to SMEs and other generic concepts such as R\&D cooperation. In the subsequent periods, from 2013 onwards, research was related to entrepreneurship, to the analysis of the Helix models, or to commercialisation as a motivating effect of knowledge transfer, as seen from the university. Finally, with regard to the areas which have not been sufficiently dealt with in the sample research, it should be pointed out that, despite the importance which the literature itself attributes to family businesses and SMEs, research has been almost non-existent in the case of the former. In the case of SMEs, there was some production of research in the first period, to be witnessed from 2013 onwards.

\section{Future Research}

As far as future research related to OI and university is concerned, we understand that there are two fronts on which to expand the literature. On the one hand, those less researched issues, such as the relationship between these two concepts and the family business or SMEs and, on the other, those that are currently showing some interest and still need to be developed, such as the strategic orientation of R\&D or the management of education towards the internalisation of $\mathrm{OI}$ in the organisational culture.

Author Contributions: Conceptualisation, J.H. and C.d.1.H.-R.; methodology, J.H. and C.d.1.H.-R.; software, J.H. and C.d.1.H.-R.; validation, J.H. and C.d.1.H.-R.; formal analysis, J.H. and C.d.1.H.-R.; investigation, J.H. and C.d.1.H.-R.; resources, J.H. and C.d.1.H.-R.; writing-original draft preparation, J.H. and C.d.l.H.-R.; writing-review and editing, J.H. and C.d.l.H.-R.; visualisation and supervision, J.H. and C.d.l.H.-R.; project administration, J.H. and C.d.l.H.-R. All authors have read and agreed to the published version of the manuscript.

Funding: This research received no external funding.

Data Availability Statement: The data presented in this study are openly available in [zenodo] at [https://doi.org/10.5281/zenodo.4420307].

Acknowledgments: We are very grateful to Universidad de Málaga.

Conflicts of Interest: The authors declare no conflict of interest.

\section{References}

1. Schumpeter, J. Capitalism, Socialism and Democracy; Harper \& Row: New York, NY, USA, 1934.

2. Tushman, M.T.; Nadler, D. Organizing for Innovation. Calif. Manag. Rev. 1986, 28, 74-92. [CrossRef]

3. Chandler, A.D., Jr. The Visible Hand: The Managerial Revolution in American Businesss, 13th ed.; The Belknap Press of Harvard University Press: Cambridge, MA, USA, 1977.

4. Freeman, C. The Economics of Industrial Innovation, 3rd ed.; MIT Press: Cambridge, MA, USA, 1997.

5. Dewar, R.D.; Dutton, J.E. The adoption of radical and incremental innovations: An empirical analysis. Manag. Sci. 1986, 32, 1422-1433. [CrossRef]

6. Utterback, J.M.; Abernathy, W. A dynamic model of process and product innovation. Omega 1975, 33, 639-656. [CrossRef]

7. Damanpour, F.; Walker, R.M.; Avellaneda, C.N. Combinative effects of innovation types and organizational performance: A longitudinal study of service organizations. J. Manag. Stud. 2009, 46, 650-675. [CrossRef]

8. Totterdill, P.; Dhondt, S.; Milsome, S. Partners at Work? A Report to Europe's Policy Makers and Social Partners; The Work Institute: Nottingham, UK, 2002.

9. Hamel, G. The why, what and how of management innovation. Harv. Bus. Rev. 2006, 84, 72-84.

10. Kemp, R.; Soete, L.; Weehuizen, R. Towards an effective eco-innovation policy in a globalised setting. In A Handbook of Globalisation and Environmental Policy; Wijen, F., Zoeterman, K., Pieters, J., van Seters, P., Eds.; Edward Elgar: Cheltenham, UK, 2005 ; pp. 155-178.

11. Cainelli, G.; Evangelista, R.; Savona, M. The impact of innovation on economic performance in services. Serv. Ind. J. 2004, 24, 116-130. [CrossRef]

12. Chesbrough, H. Open Innovation: The New Imperative for Creating and Profiting from Technology; Harvard Business School Press: Boston, MA, USA, 2003.

13. Perkmann, M.; Walsh, K. University-industry relationships and open innovation: Towards a research agenda. Int. J. Manag. Rev. 2007, 9, 259-280. [CrossRef] 
14. Randhawa, K.; Wilden, R.; Hohberger, J. A bibliometric review of open innovation: Setting a research agenda. J. Prod. Innov. Manag. 2016, 33, 750-772. [CrossRef]

15. Bogers, M.; West, J. Managing distributed innovation: Strategic utilization of open and user innovation. Creat. Innov. Manag. 2012, 21, 61-75. [CrossRef]

16. Chesbrough, H. Open Business Models: How to Thrive in the New Innovation Landscape; Harvard Business School Press: Boston, MA, USA, 2006.

17. Chesbrough, H.; Crowther, A.K. Beyond high tech: Early adopters of open innovation in other industries. RD Manag. 2006, 36, 229-236. [CrossRef]

18. Laursen, K.; Salter, A. Searching high and low: What types of firms use universities as a source of innovation? Res. Policy 2004, 33, 1201-1215. [CrossRef]

19. Coombs, R.; Harvey, M.; Tether, B.S. Analysing distributed processes of provision and innovation. Ind. Corp. Chang. 2003, 12, 1125-1155. [CrossRef]

20. Powell, W.W.; Koput, K.W.; Smith-Doerr, L. Interorganizational collaboration and the locus of innovation: Networks of learning in biotechnology. Adm. Sci. Q. 1996, 41, 116. [CrossRef]

21. Etzkowitz, H.; Leydesdorff, L. The Triple Helix-University-industry-government relations: A laboratory for knowledge based economic development. Easst Rev. 1995, 14, 14-19.

22. Cooke, P. Regionally asymmetric knowledge capabilities and open innovation: Exploring "Globalisation 2"-A new model of industry organisation. Res. Policy 2005, 34, 1128-1149. [CrossRef]

23. Weckowska, D. Learning in university technology transfer offices: Transactions-focused and relations-focused approaches to commercialization of academic research. Technovation 2015, 41-42, 62-74. [CrossRef]

24. Hayter, C. Harnessing university entrepreneurship for economic growth: Factors of success among university spin-offs. Econ. Dev. Q. 2013, 27, 18-28. [CrossRef]

25. Simeth, M.; Raffo, J.D. What makes companies pursue an open science strategy? Res. Policy 2013, 42, 1531-1543. [CrossRef]

26. Markman, G.; Siegel, D.; Wright, M. Research and technology commercialization. J. Manag. Stud. 2008, 45, 1401-1423. [CrossRef]

27. O'Shea, R.; Chugh, H.; Allen, T. Determinants and consequences of university spinoff activity: A conceptual framework. J. Technol. Transf. 2008, 33, 653-666. [CrossRef]

28. Rothaermel, F.T.; Agung, S.; Jiang, L. University entrepreneurship: A taxonomy of the literature. Ind. Corp. Chang. 2007, 16, 691-791. [CrossRef]

29. Weerasinghe, I.M.S.; Dedunu, H.H. Contribution of academics to university-industry knowledge exchange: A study of open innovation in Sri Lankan universities. Ind. High. Educ. 2020. [CrossRef]

30. Young, B.; Hewitt-Dundas, N.; Roper, S. Intellectual Property management in publicly funded R\&D centres-A comparison of university-based and company-based research centres. Technovation 2008, 28, 473-484. [CrossRef]

31. Freitas, I.M.B.; Geuna, A.; Rossi, F. Finding the right partners: Institutional and personal modes of governance of universityindustry interactions. Res. Policy 2013, 42, 50-62. [CrossRef]

32. Kleyn, D.; Kitney, R.; Atun, R.A. Partnership and innovation in the life sciences. Int. J. Innov. Manag. 2007, 11, 323-347. [CrossRef]

33. Galán-Muros, V.; Plewa, C. What drives and inhibits university-business cooperation in Europe? A comprehensive assessment. RD Manag. 2016, 46, 369-382. [CrossRef]

34. Hagedoorn, J.; Link, A.N.; Vonortas, N.S. Research partnerships. Res. Policy 2000, 29, 567-586. [CrossRef]

35. Harabi, N. Innovation through vertical relations between firms, suppliers and customers: A study of German firms. Ind. Innov. 1998, 5, 157-181. [CrossRef]

36. Oliver, A.L.; Liebeskind, J.P. Three levels of networking for sourcing intellectual capital in biotechnology: Implications for studying interorganisational networks. Int. Stud. Manag. Organ. 1998, 27, 76-103. [CrossRef]

37. Agrawal, A. University-to-industry knowledge transfer: Literature review and unanswered questions. Int. J. Manag. Rev. 2001, 3, 285-302. [CrossRef]

38. Mowery, D.C.; Nelson, R.R. (Eds.) Ivory Tower and Industrial Innovation: University-Industry Technology Before and After the Bayh-Dole Act; Stanford University Press: Stanford, CA, USA, 2004.

39. Poyago-Theotoky, J.; Beath, J.; Siegel, D.S. Universities and fundamental research: Reflections on the growth of university-industry partnerships. Oxf. Rev. Econ. Policy 2002, 18, 10-21. [CrossRef]

40. Rayna, T.; Striukova, L. University-industry knowledge exchange: An exploratory study of Open Innovation in UK universities. Eur. J. Innov. Manag. 2015, 18, 471-492. Available online: https://ssrn.com/abstract=2412632 (accessed on 12 January 2021).

41. Abreu, M.; Grinevich, V.; Hughes, A.; Kitson, M. Knowledge Exchange between Academics and the Business, Public and Third Sectors; Centre for Business Research and UK IRC, University of Cambridge: Cambridge, UK, 2009.

42. Perkmann, M.; Walsh, K. Engaging the scholar: Three forms of academic consulting and their impact on universities and industry. Res. Policy 2008, 37, 1884-1891. [CrossRef]

43. Howells, J.; Nedeva, M.; Georghiou, L. Industry-Academic Links in the UK; Manchester PREST: University of Manchester: Manchester, UK, 1998.

44. Guerrero, D.F. Industry-university collaboration in rural and metropolitan regions: What is the role of graduate employment and external non-university knowledge? J. Rural Stud. 2020, 78, 516-530. [CrossRef] 
45. Corsi, S.; Fu, X.; Külzer-Sacilotto, C. Boundary spanning roles in cross-border university-industry collaboration: The case of Chinese multinational corporations. RD Manag. 2020. [CrossRef]

46. Etzkowitz, H.; Webster, A.; Gebhardt, C.; Terra, B.R.C. The future of the university and the university of the future: Evolution of ivory tower to entrepreneurial paradigm. Res. Policy 2000, 29, 313-330. [CrossRef]

47. Florida, R.; Cohen, W.M. Engine or infrastructure? The university role in economic development. In Industrializing Knowledge: University-Industry Linkages in Japan and the United States; Branscomb, L.M., Kodama, F., Florida, R., Eds.; MIT Press: Cambridge, UK, 1999; pp. 589-610.

48. Zerhouni, E. The NIH roadmap. Science 2003, 302, 63-72. [CrossRef]

49. Stiglitz, J.; Wallsten, S. Public-private technology partnerships: Promises and pitfalls. Am. Behav. Sci. 1999, 52, 43-73. [CrossRef]

50. Greenaway, D.; Haynes, M. Funding Universities to Meet National and International Challenges. Nottingham: School of Economics Policy Report; University of Nottingham: Nottingham, UK, 2000.

51. Ruangpermpool, S.; Igel, B.; Siengthai, S. Trust and dynamic governance mechanisms in the university-industry R\&D alliances. J. Sci. Technol. Policy Manag. 2020, 11, 171-192. [CrossRef]

52. Suh, Y.; Woo, C.; Koh, J.; Jeon, J. Analysing the satisfaction of university-industry cooperation efforts based on the Kano model: A Korean case. Technol. Forecast. Soc. Chang. 2019, 148, 119740. [CrossRef]

53. Manville, G.; Karakas, F.; Polkinghorne, M.; Petford, N. Supporting open innovation with the use of a balanced scorecard approach: A study on deep smarts and effective knowledge transfer to SMEs. Prod. Plan. Control 2019, 30, 842-853. [CrossRef]

54. Mroczkowski, T.; Miller, M. Envisioning smart development in poland from a triple helix systems perspective: A critical assessment of the Morawiecki Plan. J. Knowl. Econ. 2017, 8, 513-535. [CrossRef]

55. Resende, D.N.; Bravo, M. A Top-down and Bottom-up Approach to Improve Regional Innovation Ecosystems in Portugal. Braz. J. Oper. Prod. Manag. 2016, 13, 86-93. [CrossRef]

56. Pervan, S.; Al-Ansaari, Y.; Xu, J. Environmental determinants of open innovation in Dubai SMEs. Ind. Mark. Manag. 2015, 50, 60-68. [CrossRef]

57. De Pablos, C.H.; Ruiz, J.M.B. Fostering Innovation in the National Systems: An Application to Spain. Bus. Syst. Res. J. 2014, 5, 110-124. [CrossRef]

58. Van Geenhuizen, M.; Soetanto, D.P. Open innovation among university spin-off firms: What is in it for them, and what can cities do? Innov. Eur. J. Soc. Sci. Res. 2012, 25, 191-207. [CrossRef]

59. D'Este, P.; Patel, P. University-industry linkages in the UK: What are the factors underlying the variety of interactions with industry? Res. Policy 2007, 36, 1295-1313. [CrossRef]

60. Seashore, K.L.; Blumenthal, D.; Gluck, M.; Stoto, M.A. Entrepreneurs in academe: An exploration of behaviors among life scientists. Adm. Sci. Q. 1989, 34, 110-131. [CrossRef]

61. Lee, Y.S. The sustainability of university-industry research collaboration: An empirical assessment. J. Technol. Transf. 2000, 25, 111-133. [CrossRef]

62. Ham, R.M.; Mowery, D.C. Improving the effectiveness of public-private R\&D collaboration: Case studies at a US weapons laboratory. Res. Policy 1998, 26, 661-675. [CrossRef]

63. Link, A.N. Case study of R\&D efficiency in an ATP joint venture. J. Technol. Transf. 1998, 23, 43-51. [CrossRef]

64. Rauter, R.; Globocnik, D.; Perl-Vorbach, E.; Baumgartner, R.J. Open innovation and its effects on economic and sustainability innovation performance. J. Innov. Knowl. 2019, 4, 226-233. [CrossRef]

65. D'Angelo, A.; Baroncelli, A. An investigation over inbound open innovation in SMEs: Insights from an Italian manufacturing sample. Technol. Anal. Strateg. Manag. 2020, 32, 542-560. [CrossRef]

66. Naqshbandi, M.M. Managerial ties and open innovation: Examining the role of absorptive capacity. Manag. Decis. 2016, 54, 2256-2276. [CrossRef]

67. Howells, J.; Ramlogan, R.; Shu-Li, C. Universities in an open innovation system: A UK perspective. Int. J. Entrep. Behav. Res. 2012, 18, 440-456. [CrossRef]

68. Inauen, M.; Schenker-Wicki, A. The impact of outside-in open innovation on innovation performance. Eur. J. Innov. Manag. 2011, 14, 496-520. [CrossRef]

69. Mention, A.L. Co-operation and co-opetition as open innovation practices in the service sector: Which influence on innovation novelty? Technovation 2011, 31, 44-53. [CrossRef]

70. Cruz-González, J.; López-Sáez, P.; Navas-López, J.E. Absorbing knowledge from supply-chain, industry and science: The distinct moderating role of formal liaison devices on new product development and novelty. Ind. Mark. Manag. 2015, 47, 75-85. [CrossRef]

71. Artz, K.W.; Norman, P.M.; Hatfield, D.E.; Cardinal, L.B. A longitudinal study of the impact of R\&D, patents, and product innovation on firm performance. J. Prod. Innov. Manag. 2010, 27, 725-740. [CrossRef]

72. Belderbos, R.; Cassiman, B.; Faems, D.; Leten, B.; Van Looy, B. Co-ownership of intellectual property: Exploring the valueappropriation and value-creation implications of co-patenting with different partners. Res. Policy 2014, 43, 841-852. [CrossRef]

73. Salter, A.; Criscuolo, P.; Ter Wal, A.L. Coping with open innovation: Responding to the challenges of external engagement in R\&D. Calif. Manag. Rev. 2014, 56, 77-94. [CrossRef]

74. Padilla-Meléndez, A.; Garrido-Moreno, A. Open innovation in universities: What motivates researchers to engage in knowledge transfer exchanges? Int. J. Entrep. Behav. Res. 2012, 18, 417-439. [CrossRef] 
75. Cohen, W.M.; Levinthal, D.A. Absorptive-capacity-A new perspective on learning and innovation. Adm. Sci. Q. 1990, 35, 128-152. [CrossRef]

76. Zahra, S.A.; George, G. Absorptive capacity: A review, reconceptualization, and extension. Acad. Manag. Rev. 2002, 27, 185-203. [CrossRef]

77. Lane, P.J.; Koka, B.R.; Pathak, S. The reification of absorptive capacity: A critical review and rejuvenation of the construct. Acad. Manag. Rev. 2006, 31, 833-863. [CrossRef]

78. Bogers, M.; Lhuillery, S. A functional perspective on learning and innovation: Investigating the organization of absorptive capacity. Ind. Innov. 2011, 18, 581-610. [CrossRef]

79. Katz, R.; Allen, T.J. Investigating the not invented here (NIH) syndrome-A look at the performance, tenure, and communication patterns of 50 R-AND-D project groups. RD Manag. 1982, 12, 7-19. [CrossRef]

80. Cassiman, B.; Veugelers, R. In search of complementarity in innovation strategy: Internal R\&D and external knowledge acquisition. Manag. Sci. 2006, 52, 68-82. [CrossRef]

81. Hughes, B.; Wareham, J. Knowledge arbitrage in global pharma: A synthetic view of absorptive capacity and open innovation. RD Manag. 2010, 40, 324-343. [CrossRef]

82. Tether, B.S.; Tajar, A. Beyond industry-university links: Sourcing knowledge for innovation from consultants, private research organisations and the public science-base. Res. Policy 2008, 37, 1079-1095. [CrossRef]

83. Miller, K.; McAdam, R.; Moffett, S.; Alexander, A.; Puthusserry, P. Knowledge transfer in university quadruple helix ecosystems: An absorptive capacity perspective. RD Manag. 2016, 46, 383-399. [CrossRef]

84. Todorova, G.; Durisin, B. Absorptive capacity: Valuing a reconceptualization. Acad. Manag. Rev. 2007, 32, 774-786. [CrossRef]

85. Lichtenthaler, U. Open innovation in practice: An analysis of strategic approaches to technology transactions. Eng. Manag. IEEE Trans. 2008, 55, 148-157. [CrossRef]

86. Hemert, P.; Nijkamp, P.; Masurel, E. From innovation to commercialization through networks and agglomerations: Analysis of sources of innovation, innovation capabilities and performance of Dutch SMEs. Ann. Reg. Sci. 2013, 50, 425-452. [CrossRef]

87. Carpinetti, L.C.R.; Gerolamo, M.C.; Galdamez, E.V.C. Continuous Innovation and Performance Management of SME Clusters. Creat. Innov. Manag. 2007, 16, 376-385. [CrossRef]

88. Van de Vrande, V.; De Jong, J.P.J.; Vanhaverbeke, W.; De Rochemont, M. Open innovation in SMEs: Trends, motives and management challenges. Technovation 2009, 29, 423-437. [CrossRef]

89. Bianchi, M.; Campodall'Orto, S.; Frattini, F.; Vercesi, P. Enabling open innovation in small- and medium-sized enterprises: How to find alternative applications for your technologies. RD Manag. 2010, 40, 414-431. [CrossRef]

90. Albors-Garrigos, J.; Etxebarria, N.Z.; Hervas-Oliver, J.L.; Epelde, J.G. Outsourced innovation in SMEs: A field study of R\&D units in Spain. Int. J. Technol. Manag. 2011, 55, 138-155. [CrossRef]

91. Caetano, M.; Amaral, D.C. Roadmapping for technology push and partnership: A contribution for open innovation environments. Technovation 2011, 31, 320-335. [CrossRef]

92. Christensen, J.F.; Olesen, M.H.; Kjær, J.S. The industrial dynamics of open innovation-evidence from the transformation of consumer electronics. Res. Policy 2005, 34, 1533-1549. [CrossRef]

93. Goduscheit, R.C.; Knudsen, M.P. How Barriers to Collaboration Prevent Progress in Demand for Knowledge: A Dyadic Study of Small and Medium-Sized Firms, Research and Technology Organizations and Universities. Creat. Innov. Manag. 2015, $24,29-54$. [CrossRef]

94. Technovation Journal. Elsevier. Available online: https:/ / www.journals.elsevier.com/technovation (accessed on 27 December 2020).

95. Research Policyy Journal. Elsevier. Available online: https:/ /www.journals.elsevier.com/research-policy (accessed on 27 December 2020).

96. World Open Innovation Conference WOIC. Available online: https://woic.corporateinnovation.berkeley.edu/ (accessed on 27 December 2020).

97. Conference of Open Innovation Association FRUCT. Available online: https: / / www.fruct.org/cfp26 (accessed on 27 December 2020).

98. Journal of Open Innovation: Technology, Market, and Complexity. MDPI. Available online: https://www.mdpi.com/journal/JOItmC (accessed on 27 December 2020).

99. Vanhaverbeke, W.; Roijakkers, N.; Usman, M.; Frattini, F. (Eds.) . Researching Open Innovation in SMEs; World Scientific: Singapore, 2018.

100. Albort-Morant, G.; Soriano, D.R. A bibliometric analysis of international impact of business incubators. J. Bus. Res. 2016, 69, 1775-1779. [CrossRef]

101. Chen, G.; Xiao, L. Selecting publication keywords for domain analysis in bibliometrics: A comparison of three methods. J. Inf. 2016, 10, 212-223. [CrossRef]

102. Rey-Martí, A.; Soriano, D.R.; Marqués, D.P. A bibliometric analysis of social entrepreneurship. J. Bus. Res. 2016, 69, 1651-1655. [CrossRef]

103. Web of Science. Fundación Española Para la Ciencia y la Tecnología FEYCT. Available online: https:/ / www.recursoscientificos. fecyt.es / (accessed on 27 December 2020).

104. Cobo, M. SciMAT: Software Tool for the Analysis of the Evolution of Scientific Knowledge. Proposal for an Evaluation Methodology. Ph.D. Thesis, University of Granada, Granada, Spain, 2011.

105. Price, D.; Gürsey, S. Studies in scientometrics I: Transience and continuance in scientific authorship. Ci. Inform. 1975, 4, 27-40.

106. Secundo, G.; Mele, G.; Del Vecchio, P.; Degennaro, G. Knowledge spillover creation in university-based entrepreneurial ecosystem: The role of the Italian “Contamination Labs". Knowl. Manag. Res. Pract. 2020, 1-15. [CrossRef] 
107. Sarkar, S. Uncorking knowledge-purposeful spillovers as a strategic tool for capability enhancement in the cork industry. Int. Entrep. Manag. J. 2017, 13, 251-275. [CrossRef]

108. Herrera, J.; de las Heras-Rosas, C. Economic, Non-Economic and Critical Factors for the Sustainability of Family Firms. J. Open Innov. Technol. Mark. Complex. 2020, 6, 119. [CrossRef]

109. Spithoven, A.; Vanhaverbeke, W.; Roijakkers, N. Open innovation practices in SMEs and large enterprises. Small Bus. Econ. 2013, 41, 537-562. [CrossRef]

110. Hossain, M. Open innovation: So far and a way forward. World J. Sci. Technol. Sustain. Dev. 2013, 10, 30-41. [CrossRef]

111. Wynarczyk, P.; Piperopoulos, P.; McAdam, M. Open innovation in small and medium-sized enterprises: An overview. Int. Small Bus. J. 2013, 31, 240-255. [CrossRef]

112. Hossain, M.; Kauranen, I. Open innovation in SMEs: A systematic literature review. J. Strategy Manag. 2016, 9, 58-73. [CrossRef] 